\title{
A fast and practical method for initial diagnosis of Piscinoodinium pillulare outbreaks: piscinootest
}

\section{Ana Lucia Silva Gomes ${ }^{1}$ Jesaías Ismael da Costa ${ }^{2}$ Maria Linda Flora de Novaes Benetton ${ }^{1}$ Geraldo Bernardino ${ }^{3}$ Andrea Belem-Costa ${ }^{4^{*}}$}

${ }^{1}$ Laboratório de Parasitologia de Peixes, Universidade Federal do Amazonas (UFAM), Manaus, AM, Brasil

${ }^{2}$ Centro de Aquicultura (CAUNESP), Universidade Estadual Paulista Júlio de Mesquita Filho (UNESP), Jaboticabal, SP, Brasil.

${ }^{3}$ Secretaria de Pesca e Aquicultura (SEPA), Secretaria de Estado da Produção Rural (SEPROR-AM), Manaus, AM, Brasil.

${ }^{4}$ Laboratório de Imunologia de Animais Aquáticos, Universidade Federal do Amazonas (UFAM), Av. Rodrigo Octávio, 6200, Coroado, 69080900, Manaus, AM, Brasil. E-mail: andreabelem2@gmail.com. ${ }^{*}$ Corresponding author.

ABSTRACT: The dinoflagellate Piscinoodinium pillulare is a parasite with low parasitic specificity and unspecific geographical distribution. This research reported a simple and practical method - the principle of spontaneous sedimentation - to identify the presence of P. pillulare during massive infestations which does not require using precision equipment. Agitation in water of the gill arches of infested fish will elicit, after a period of rest, recording the accumulation of trophonts in the bottom of flasks. The method was applied during outbreaks of P. pillulare in tambaqui, Colossoma macropomum and matrinxã, Brycon amazonicus, in fish farms of the Amazon region and proved to be effective. Key words: fish parasite, dinoflagellate, piscinoodiniasis.

Um método rápido e prático para o diagnóstico inicial de surtos de Piscinoodinium pillulare: piscinootest

RESUMO: O dinoflagelado Piscinoodinium pillulare é um parasita com baixa especificidade parasitária e distribuição geográfica não especifica. Este trabalho reporta um método simples e prático - o princípio da sedimentação espontânea - para identificar a presença de P. pillulare durante infestações maciças, que não requer o uso de equipamentos de precisão. A agitação em água dos arcos branquiais de peixes infestados permite, após um periodo de repouso, registrar o acúmulo de trofontes no fundo dos frascos. O método foi aplicado durante os surtos de P. pillulare em tambaqui, Colossoma macropomum e matrinxã, Brycon amazonicus, em pisciculturas comerciais da região Amazônica e provou ser eficaz.

Palavras-chave: parasita de peixes, dinoflagelado, piscinoodiniasis.

The dinoflagellate Piscinoodinium pillulare (Schäperclaus 1954) LOM 1981, is a parasite with low parasitic specificity recorded worldwide (SHAHAROM-HARRISON et al., 1990; RAMESH et al., 2000; NOGA \& LEVY, 2006) and in different Brazilian regions infecting different host species: Nile tilapia, Oreochromis niloticus (MARTINS et al., 2001, ZAGO et al. 2014), common carp, Cyprinus carpio (SCHALCH \& MORAES, 2005), surubimpintado, Pseudoplatystoma corruscans (EIRAS et al., 2009), curimbata, Prochilodus lineatus (CAMPOS et al., 2011), blackwing hatchetfish, Carnegiella marthae (TAVARES-DIAS et al., 2010), corydora, Corydoras spp. (FERRAZ \& SOMMERVILLE, 1998), and oscar, Astronotus ocellatus (NEVES et al., 2013).
Pathogenic action of $P$. pillulare, the causative agent of velvet disease, is fast and efficient, leading to high mortalities in a short period of time. Parasite binds to host cells through rhizocysts, which may cause cell necrosis, bleeding points in the integument, hypertrophy and fusion of the secondary lamellae of gills, which results in severe respiratory deficiency and mortality (MARTINS et al., 2001). In southeastern Brazil, P. pillulare infestations have been reported to cause mortalities of more than 4,000 fish in 24 hours (MARTINS et al. 2001). Unlike other regions where outbreaks are markedly seasonal, $P$. pillulare has caused outbreaks with high mortality in matrinxã and tambaqui farms throughout the year in the Amazon region. 
The microscopic nature of the parasite requires specialized equipment for accurate identification, a condition not accessible to most people who work in fish farming. Late registrations of infestation hampers effectiveness of control measures. Developing practical, accessible, and quick diagnosis techniques for piscinoodinosis thus comes as an immediate need, and such was the aim of this study.

The method targets situations of high mortality of unknown origin in ponds, especially when associated to the presence of dying fish with erratic swimming on the pond surface, fish with excess mucus and brown or greenish coloration. The presence of birds of prey on ponds banks is an additional indication of recent death in the environment.

The piscinootest consists of the careful excision and removal of excess blood of gill arches from fish with provisional diagnosis of piscinoodiniasis (Figure 1A). A total of 60 fish were examined. The gill arches of five fish were placed in transparent vials and the material covered with filtered or distilled water, up to twice the volume. The vial shall then be gently, hand shaken for three minutes and allowed to rest for about thirty minutes for sedimentation of the suspended material (Figure 1B). After the resting period, trophonts (green dots) will accumulate in the bottom of the bottle (Figure 1C), thus eliciting the diagnosis by piscinoodiniasis. A better visualization of the trophonts can be obtained by positioning the bottle against light. This technique should not be applied to dead fish floating in the ponds because of the excess of mucus that makes difficult the visualization of trophonts in the vail.

This method was tested in outbreaks of piscinoodinosis in rural properties in the Amazon region, especially tambaqui and matrinxã farms. In all cases, outbreaks of $P$. pillulare were identified in fish presenting clinical signs - anorexic, apathy, loss of equilibrium and erratic swimming, breathing difficulty and crowding of fish stock around the water supply tube, green or brown coloration and epidermis with mucus excess. In the advanced phases of infestation, hemorrhagic spots on the body surface and high mortality were recorded, which corroborates the reports of piscinoodiniasis in fish from Brazilian locations (MARTINS et al., 2001, SANT'ANA et al., 2012).

Field diagnosis from piscinootest was validated by laboratory tests using the conventional method of assembly of the blade material after scraping of the body and gill surfaces of infested fish and observation under an optical microscope. Registering oval and pyriform trophont forms, characteristic of $P$. pillulare, attested the effectiveness of the method. The method should be evaluated with Amyloodinium, the marine counterpart of Piscinoodinium (REED and FLOYD, 1994).

The piscinootest proved to be effective and suitable for use in field situations. The early diagnosis of piscinoodiniasis is important for the decision-making of technicians and producers to reduce or control the devastating effects of the parasite on fish farms.

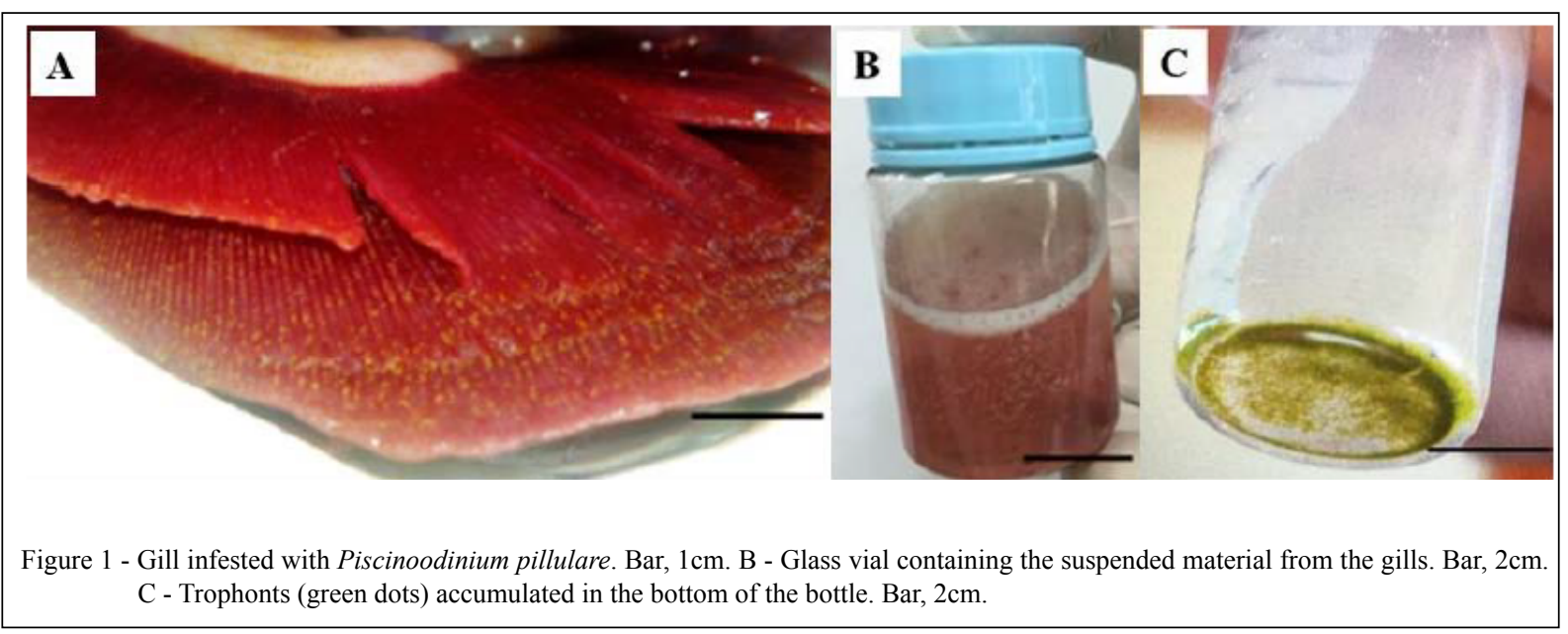

Ciência Rural, v.48, n.7, 2018. 


\section{ACKNOWLEDGMENTS}

The authors are grateful for the financial support of Financiadora de Estudos e Projetos (FINEP), under the Project Development of Aquaculture and Fishing Resources in Central Amazonia (DARPA) (Agreement: 01.09.0472.00 Financiadora de Estudos e Projetos (FINEP)/FDB/Secretaria de Estado da Produção Rural de Amazonas (SEPROR-AM)), and to Dr. J.E.P. Cyrino, Escola Superior de Agricultura Luiz de Queiroz da Universidade de São Paulo (ESALQ-USP) for the manuscript review.

\section{DECLARATION OF CONFLICTING OF INTERESTS}

The authors declared no potential conflicts of interest with respect to the research, authorship, and/or publication of this article.

\section{REFERENCES}

EIRASJ.C., R. etal.Henneguya corruscansn. sp.(Myxozoa, Myxosporea, Myxobolidae), a parasite of Pseudoplatystoma corruscans (Osteichthyes, Pimelodidae) from the Paraná River, Brazil: a morphological and morphometric study. Veterinary Parasitology, v.159, p.154-158, 2009. Available from: <https://doi.org/10.1016/j.vetpar.2008.10.020>. Accessed: Sep. 15, 2017. doi: 10.1016/j.vetpar.2008.10.020.

FERRAZ E.; SOMMERVILLE, C. Pathology of Piscinoodinium sp. (Protozoa: Dinoflagellida), parasites of the ornamental freshwater cattishes Corydoras spp. and Brochis splendens (Pisces: Callichthyidae). Diseases of Aquatic Organisms, v.33, p.43-49, 1998. Available from: $<$ http://www.int-res.com/abstracts/dao/v33/n1/p43-49>. Accessed: Sep. 15, 2017. doi: 10.3354/dao033043.

MARTINS M.L. et al. Piscinoodinium pillulare (Schäperclaus, 1954) Lom, 1981 (Dinoflagellida) infection in cultivated freshwater fish from the Northeast region of São Paulo State, Brazil: parasitological and pathological aspects. Brazilian Journal of Biology, v.61, p.639-644, 2001. Available from: $<$ http://www.scielo.br/scielo.php?script=sci_arttext\&pid=S151969842001000400013\&lng=en\&nrm $=$ iso $>$. Accessed: Sep. 15 2017. doi: 10.1590/S1519-69842001000400013.

NEVES, L.R. et al. Seasonal influence on the parasite fauna of a wild population of Astronotus ocellatus (Perciformes: Cichlidae) from the Brazilian Amazon. Journal of Parasitology, v.99, n.4, p.718-721, 2013. Available from: <http://www.bioone.org/doi/abs/10.1645/1284.1>. Accessed: Jan. 23, 2018. doi: 10.1645/12-84.1.
NOGA E.J.; LEVY M.G. Phylum Dinoflagellata. In: WOO, P.T.K. (Ed.). Fish Diseases and Disorders: Protozoan and Metazoan Infections. Oxford: CABI, 2006. Chap. 2. p.16-45.

RAMESH K.S. et al. Piscinoodinium sp. infection in juveniles of common carp (Cyprinus carpio), mahseer (Tor khudree) and tilapia (Oreochromis mossambicus). Journal of Aquaculture in the Tropics, v.15, p. 281-288, 2000. Provided by one of the authors.

REED P.; FRANCIS-FLOYD R. Amyloodinium infections of marine fish. University of Florida, IFAS Extension. Fact Sheet VM 90, p.1-3. 1994. Available from: <http://2kjj1d3odhc3296co 7jhe511.wpengine.netdna-cdn.com/files/2013/09/AmyloodiniumInfections-of-Marine-Fish.pdf>. Accessed: Jul. 30, 2017.

SANT'ANA F.J.F., et al. Surtos de infecção por Piscinoodinium pillulare e Henneguya spp. em pacus (Piaractus mesopotamicus) criados intensivamente no Sudoeste de Goiás (Outbreaks of Piscinoodinium pillulare and Henneguya spp. infection in intensively raised Piaractus mesopotamicus in Southwestern Goiás, Brazil). Brazilian Journal of Veterinary Research, v.32, p.121-125, 2012. Available from: $<$ https://repositorio.bc.ufg.br/xmlui/handle/ ri/14153>. Accessed: Sep. 21, 2017.

SCHALCH S.H.C.; MORAES F.R. Distribuição sazonal de parasitos branquiais em diferentes espécies de peixes em pesque-pague do município de Guariba-SP, Brasil. (in Portuguese). Brazilian Journal of Veterinary Parasitology, v.14, p.141-146, 2005. Available from: <http://www.redalyc.org/ pdf/3978/397841456002.pdf $>$. Accessed: Aug. 22, 2017.

SHAHAROM-HARRISON F.M. et al. Epizootics of Malaysian cultured freshwater pond fishes by Piscinoodinium pillulare (Schäperclaus, 1954) Lom, 1981. Aquaculture, v.86, p.127-138. 1990. Available from: <http://www.sciencedirect.com/science/ article/pii/004484869090107X?via\%3Dihub>. Accessed: Sep. 21, 2017. doi: 10.1016/0044-8486(90)90107-X.

TAVARES-DIAS M. et al. Parasitic fauna of eight species of ornamental freshwater fish species from the middle Negro River in the Brazilian Amazon Region. Revista Brasileira de Parasitologia Veterinária, v.19, p.103-107, 2010. Available from: <http:/www.scielo.br/scielo. php?script=sci_arttext\&pid=S1984-29612010000200007\&lng=en\&n rm=iso $>$. Accessed: Sep. 15, 2017. doi: 10.4322/rbpv.01902007.

ZAGO A.C. et al. Ectoparasites of Nile tilapia (Oreochromis niloticus) in cage farming in a hydroelectric reservoir in Brazil. Brazilian Journal of Veterinary Parasitology, v.23, n. 2, p.171178, 2014. Available from: <http://dx.doi.org/10.1590/S198429612014041>. Accessed: Feb. 08, 2018. doi:10.1590/S198429612014041. 